\title{
Dr. William P. Coffman: Celebrating 50 Years of Research on ChIRONOMIDAE
}

\section{"Midges are an addiction. Can't get through the day without my midge fix." WPC}

Bill Coffman's addiction to midges has been a revelation and an inspiration to his students and colleagues for many years. His knowledge of the family, his uncanny ability to differentiate species by the pupal exuviae, and his enthusiasm over the range of wonders, from tiny structures to biogeographical patterns, is well known and respected. From humble beginnings at Thiel College, Pennsylvania (where he first met his wife of over 40 years), to a long and fruitful career at the University of Pittsburgh, Bill Coffman exemplifies the focus and the dedication that few scientists have for their subjects. He trained with the best, including Dr. John Stall at Thiel, Dr. Ken Cummins at Pitt and followed the steps of giants in the field through post-docs at a government laboratory in BadenWurttemberg, Germany. He also spent time at the Max Plank Institute in Plön, Germany, where names such as Thienemann, Lenz and others adorn not only the halls of the institution but the taxonomic literature as well. He has been honored with his own chironomid genus (Coffmania) and a species (Robackia coffmanii), immortalizing his name for generations to come.

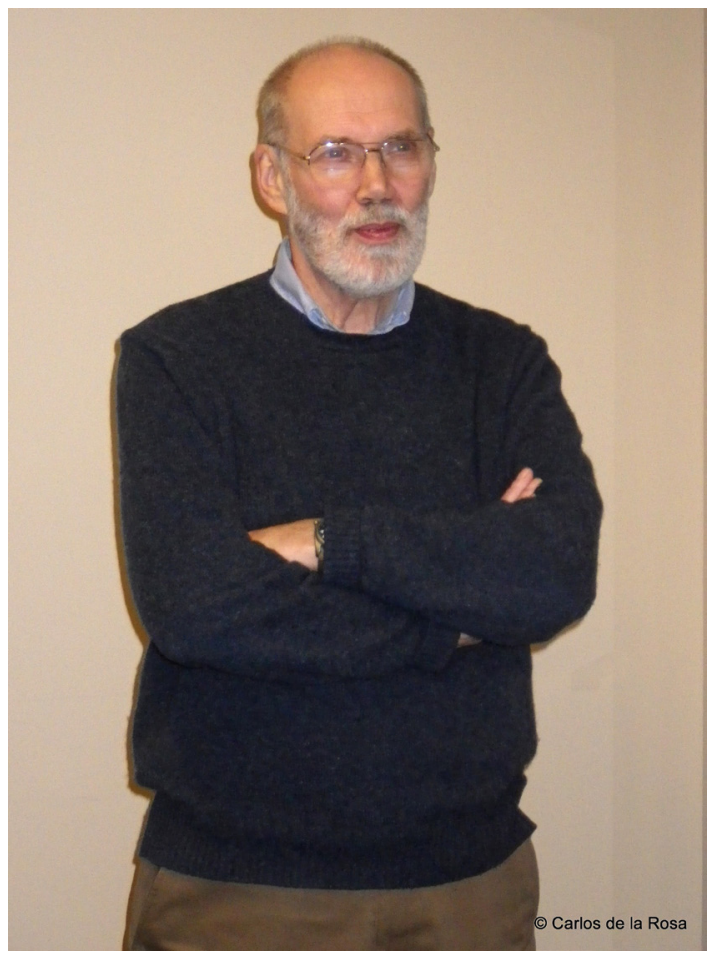

Dr. William P. Coffman, University of Pittsburgh, Pennsylvania, September 2012.
His work has delved into methodologies and defining characters, through ecology and biogeography, taxonomy and evolution. His insights into the Chironomidae family species richness and diversity, evolutionary patterns, extinction rates, biogeographical puzzles and adaptation have been profound and are likely to shape the directions in this field of research in the future. His collection of world-wide pupal exuviae is unparalleled and extensive, with over 1,000 undescribed species, many from the Neotropics. But perhaps his greatest contribution so far is a family of scientists and researchers that have been touched, bitten perhaps, by the "bug" of knowing and using this family to resolve long-standing questions of evolution, biogeography, taxonomy and conservation.

Bill Coffman's collection, now housed at the La Selva Biological Station of the Organization for Tropical Studies in Costa Rica, is the foundation for the development of species-level fine tools for bioassessment and ecology, with practical applications to habitat valuation and conservation. His undescribed species, keys and insights, captured in exquisitely prepared specimens (over 100,000 in the collection) and in his detailed notes, sketches and illustrations, will continue to train students in the fine points of chironomid taxonomy and applications. His name will continue to appear in the chironomid literature for many years after he is gone.

\section{"Chironomids are like the bacteria of the aquatic systems” WPC}

Bill Coffman thought of chironomids as the bacteria of the aquatic systems, the most diverse, species rich and ubiquitous organism in the wide range of aquatic habitats, from the Arctic Circle to the deep tropics. Midges occupy habitats unsuitable to most other organisms, able to thrive from thermal waters to ice-packed lakes; they fulfill every trophic role in aquatic ecosystems, playing the part of predators, herbivores, detritivores, filter feeders, parasites and specialists, feeding on wood, diatoms and other insects. They have an extraordinary range of life habits and an uncanny consistency of life history, which allowed specialists like Bill to learn from them how streams and lakes function. They are a family-level model of entire communities, offering species-level definition that allows us to ask questions rarely possible with other groups. In Bill's words, they are "the middle man in aquatic 


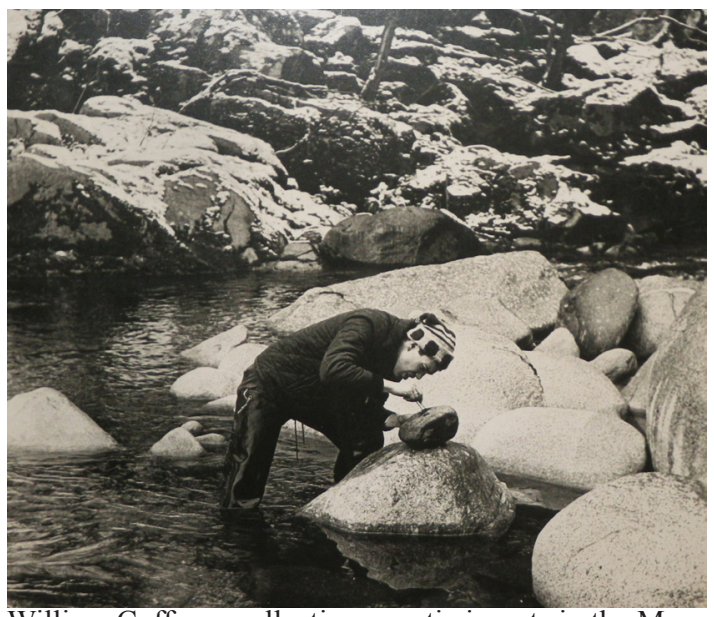

William Coffman collecting aquatic insects in the Murg River, northern Black Forest near Rogstag, Germany, 1968

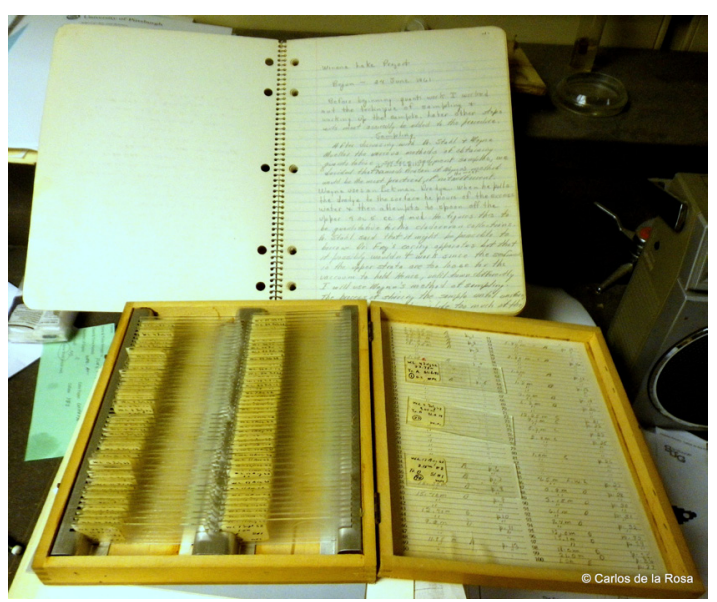

Journal and first collection of chironomids by William Coffman, Winona Lake, Indiana, 1961.

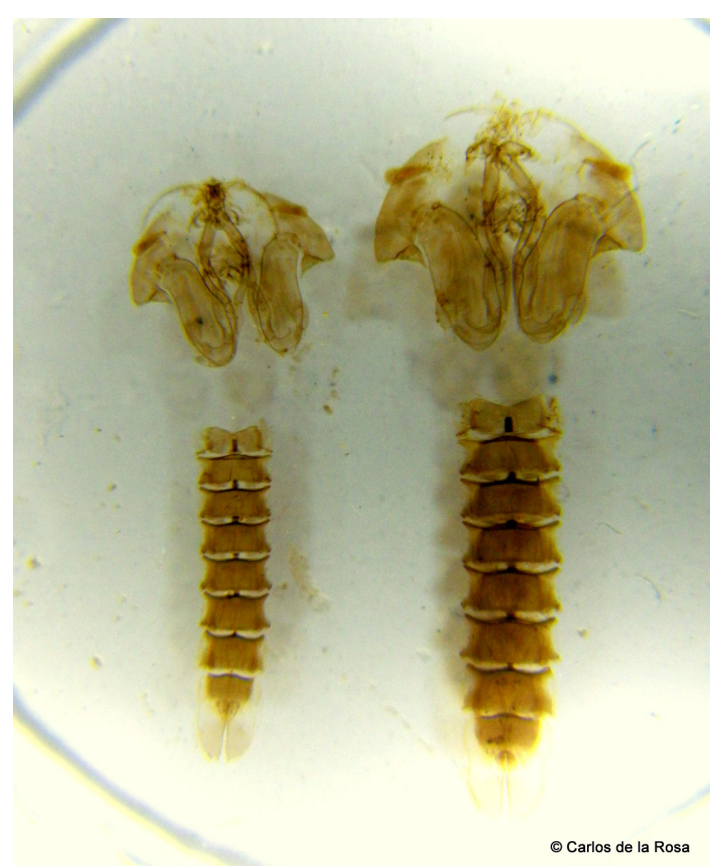

Alotanypus sp. pupal exuviae mounted by William Coffman. ecosystems," supporting and maintaining the energy flow of most freshwater ecosystems. And their diversity is barely known in much of the world. Thousands of species remain to be discovered and described, up to 20,000 estimated around the world, including perhaps the most puzzling and difficult fauna of all: terrestrial chironomids. In spite of the challenges, the accumulated knowledge that a handful of specialists like Bill Coffman have bequeathed us will continue to build through the continued work on his and other collections. It is only unfortunate that chironomid taxonomy, as a field of study, has not been pursued or supported by most world universities or institutions. Very few true specialists continue to work on the family and the new generation is not coming up in the needed numbers, at a time when the scientific world needs them the most. The current wave of species extinction, mostly through habitat destruction and compounded by climate change, will make the techniques and knowledge application of this fauna more important than ever.

\section{A new beginning for tropical chironomids}

The relocation of Bill Coffman's collections to Costa Rica, a country well known for its respect and love for biological diversity, will ensure a long life and a continued use of this amazing resource. The new William P. Coffman Laboratory of Aquatic Entomology at the La Selva Biological Station will make the collection available to scientists and students, to continue to develop it and add to it, explore it, publish its secrets and train a new generation of local ecologists and taxonomists. His unique collections from the Afrotropical Region, India and other locations around the world will be made available for regional scientists to study and build upon. The most extensive Nearctic collection of chironomid pupal exuviae, an important part of the latest version of the Nearctic Keys to the family, will be housed and curated here. Workshops on the use of chironomid pupal exuviae as tools in biodiversity surveys, bioassessments, pollution studies and habitat conservation, will truly revolutionize the way we approach river and stream conservation in the Neotropics. Printed and electronic keys will make use of the latest visualization technologies, accelerating the learning process for these new chironomid scientists. Other technologies, such as genetic barcoding, will help elucidate and resolve long standing taxonomic issues, all based on the strong foundation provided by many years of experience in anatomy and morphology. Future techniques, such as computer-assisted pattern recognition, will eventually allow students and field biologists recognize species much like we 
currently use them to recognize fingerprints and faces. And its applications to conservation, pollution monitoring and control and priority setting for conservation and management, are just some of the many upcoming benefits to society.

\section{"When a door opens, and you are young, you go for it" WPC}

During a celebration of Bill's career at the Department of Biology of the University of Pittsburgh, he recounted his early experiences in biology, as an undergraduate in Thiel College. His introduction to chironomids, like for most of us that have followed similar paths, was in part fortuitous, and in part absorbing. So many species and so many forms! How could this have evolved? He spent four summers collecting and sorting, trying to overcome the dearth in literature and the resistance from other biologists to study this difficult group. Even when redirected as a student of Ken Cummins in Pittsburgh to develop keys to all the aquatic insects of Linesville Creek, he continued to "chip away at the resistance to name" these many species, to figure out how can there be so many of them in a single stream. His doggedness paid off, inspiring a dozen students and challenging established notions. And this legacy will go on, through his papers, his extraordinary collection, his notes and drawings and his insights. His legacy will continue to open doors for those few curious students, filled with energy and frustration and deep and unfulfilled desire to learn and figure out the roots of this diversity and apply it to today's biodiversity challenges.

\section{A Passionate Scientist, a Scholar and a Teacher}

Bill Coffman is, most of all, a well-rounded scientist, dedicated to his field with a quiet but intense passion, the same passion and attention to detail

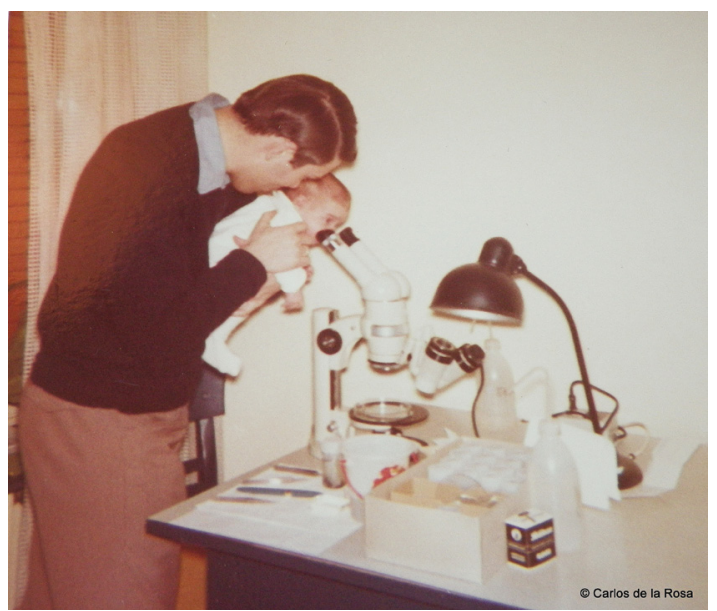

William Coffman introducing his daughter Kendal to Chironomidae, 1969.

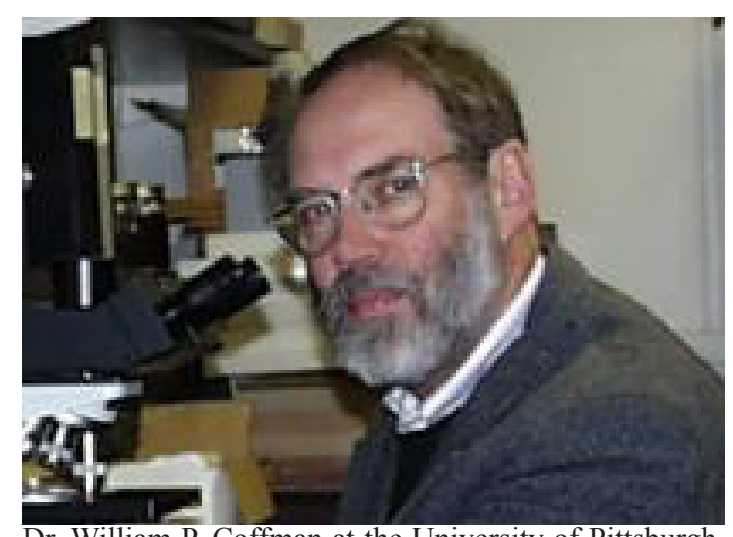

Dr. William P. Coffman at the University of Pittsburgh, Pennsylvania.

he applied to his personal life. For many years he collected stamps with a depth of knowledge and thoroughness only comparable to his knowledge of the midges. He studied history with a critical and discriminating eye, amassing an extraordinary library that he voraciously consumed and internalized. His expertise in World War II, in tropical exploration and history is hardly known by anyone outside his near family circle. He lived a relatively solitary professional life, teaching courses at Pitt (including Introductory Biology) that inspired those that cared to listen with his understanding and craving for knowledge. Largely lost in a young generation, those that did listen were inspired and moved, as the many testimonials from students attest. Bill was not one to go to many professional meetings, nor did he pursue research grants or feel that needed them. His tools were simple: two microscopes, a drawing tube, his notebooks, and few hand tools. His biggest investment was time: time to seek, see, compare, discriminate and resolve. After nearly 50 years of looking at millions of chironomid exuviae with a single-minded and hyper-trained eye, he broke through the extraordinary fog of species and resolved the characters and the keys, fine-tuning the pieces of the puzzle that have stumped researchers before him for over 100 years. Much like deciphering a hieroglyph, the tiny exuviae released their secrets to him, which he captured and preserved in his slides and notes, in his impromptu lectures to a fortunate few, in his field observations and his deep biogeographical and taxonomic insights. This is one of William Coffman's most important scientific legacies.

However, his most important legacy has been the gift of his friendship, his mentorship, his love for science and his family, his relentless pursuit of knowledge and his deep human qualities. Many people benefitted personally and professionally from their association with Bill Coffman. He developed long lasting relationships with people like 
Sam Roback, the Dean of North American chironomid workers, and Ken Cummins and is wife Peggy Wilzbach, who collected and shared many specimens from their trips around the world. Scientists like Jim Sedell, Norman Anderson, Henri Laville, Jan Sykora and former students like Rick Jacobson, Lou Yurasits, Len Ferrington, Dave Wartinbee, Bill Walker, Roger Carrillo and I (among others) benefited and made careers from our close relationship with Bill, providing specimens, insights, writing papers and developing theories that together represent the accumulated knowledge of a productive career. Our gratitude cannot be expressed with simple words, but it is immortalized by our joint accomplishments, the papers we wrote, the courses we taught, the species we discovered and the memories we shared. Thank you, Bill, for all that you have done for all of us.

\section{Selected Publications of William P. Coffman}

Coffman, W.P., and C.L. de la Rosa, 1998. Taxonomic composition and temporal organization of tropical and temperate species assemblages of lotic Chironomidae . - J. Kansas Entomol. Soc. 71: 388-406.

Coffman, W.P., and L. Ferrington, 1998. Chironomidae. Pp 635-754 in An Introduction to the Aquatic Insects of North America, 3rd Edition, Merritt, R., and K.W. Cummins, Ed. KendallHunt, Dubuque, Iowa.

Coffman, W.P., 1995. Conclusions. Pp. 436-447 in The Chironomidae: The Biology and Ecology of Non-biting Midges, Armitage, P., P.S. Cranston, and L.C.V. Pinder, Ed. Chapman and Hall, London.

Coffman, W.P., C. de la Rosa, K.W. Cummins, and M.A. Wilzbach, 1992. Species richness in some Neotropical (Costa Rica) and Afrotropical (west Africa) lotic communities of Chironomidae (Diptera). - Netherlands J. Aquatic Ecol. 26: 229-237.

Roback, S., and W.P. Coffman, 1989. Tanypodinae pupae from Southern India (Diptera: Chironomidae). - P. Acad. Nat. Sci. Philadelphia. 141: 85-113.

Coffman, W.P., 1989. Factors that determine the species richness of lotic communities of Chironomidae. Acta Biologica Debrecina, - Oecologica Hungarica Suppl. 3: 95-100.

Coffman, W.P., L. Yurasits, and C. de la Rosa, 1988. Chironomidae of South India I. Generic composition, biogeographical relationships and descriptions of two unusual pupal exuviae. - Spixiana, Suppl. 14: 155-165.

Coffman, W.P., L. Ferrington and R. Seward. 1988. Paraboreochlus stahli, sp. nov., a new species of Podonominae from the Nearctic. Aquatic Insects 10: 189-200.

Coffman, W.P., 1986. The pupae of Chironomidae of the Holarctic Region - key to Subfamilies. - Ent. Scand. Suppl. 28: 9-11.

Coffman, W.P., P.S. Cranston, D.R. Oliver, and O.A. Saether, 1986. The pupae of Orthocladiinae of the Holarctic region - keys and diagnoses. - Ent. Scand. Suppl. 28: 147-297.

Coffman, W.P. and L. Ferrington, 1984. Chironomidae. Pp. 551-652 in Merritt and Cummins, eds. An Introduction to the Aquatic Insects of North America, 2 ${ }^{\text {nd }}$. Edition. Kendall-Hunt, Dubuque, Iowa.

Coffman, W.P. and S. Roback, 1984. Lopescladius (Cordiella) hyporheicus, a new subgenus and species (Diptera: Chironomidae: Orthocladiinae). - Proc. Acad. Nat. Sci. Philadelphia 136: 130-144.

Coffman, W.P., 1983. Thoracic chaetotaxy of chironomid pupae. - Mem. Amer. Ent. Soc. 34:6170 .

Roback, S., and W.P. Coffman, 1983. Results of the Caterwood-Peruvian altiplano expedition. Part II. Aquatic Diptera including montane Diamesinae and Orthocladiinae from Venezuela. - Proc. Acad. Nat. Sci. Philadelphia 135:9 -79.

Swegman, B. and W.P. Coffman, 1980. Stenopsyche kodaikanalensis: a new species of Stenopsyche from South India. - Aquatic Insects 2: 73-79.

Coffman, W.P., 1979. Neglected characters of pupae in chironomid taxonomy and phylogeny. Ent. Scand. Suppl. 19: 37-46.

Coffman, W.P., 1978. Chironomids. In: Methods for the Assessment and Prediction of Mineral Mining Impacts on Aquatic Communities: A Review and Analysis. W. T. mason, Jr. (ed.) U.S. Dept. of Interior. Fish and Wildlife Service, Biological Services Program.

Coffman, W.P., 1978. Chapter 22: Chironomidae. In: Introduction to the Aquatic Insects of North America. Merritt R. and K.W. Cummins (eds.) Kendall-Hunt, Dubuque, Iowa.

Coffman, W.P. and W.H. Walker, 1977. A Selected Bibliography of the Chironomidae, $2^{\text {nd }}$. Edi- 
tion. Publications of the Pymatuning Lab. Of Ecology. Pp. 1-48.

Roback, S. and W.P. Coffman, 1977. New records of probable Djalmabatista species from North America and Venezuela. - Proc. Acad. Nat. Sci. Philadelphia 128: 49-54.

Wartinbee, D. and W.P. Coffman, 1976. Quantitative determination of chironomid emergence from enclosed channels in small lotic ecosystems. - Am. Midl. Nat. 95: 479-485.

Saunders, G,. W.P. Coffman, G. Michael and S. Krishnaswamy, 1974. Photosynthesis and extracellular release in ponds of S. India. - Verh. Internat. Verein. Limnol. 19: 2309-2314.

Coffman, W.P., 1974. Seasonal differences in the diel emergence of a lotic chironomid community. - Ent. Tidskr. 95: 42-48.

Gottlieb, F.G., W.P. Coffman and G.R. Carmody, 1973. The pupal respiratory organ of the Tanypodinae. The respiratory complex of $T$. carinatus var Sublette. - Int. J. Insect Morph. And Embryology 3: 147-155.
Coffman, W.P., 1973. Energy flow in a woodland stream ecosystem: II. The taxonomic composition and phenology of the Chironomidae as determined by the collection of pupal exuviae. - Arch. Hydrobiol. 71: 281-322.

Cofmman, W.P., K.W. Cummins and J.C. Wuycheck, 1971. Energy flow in a woodland stream ecosystem: I. Tissue support tropic structure of the autumnal community. - Arch. Hydrobiol. 68: 292-276.

Cummins, K.W., W.P. Coffman and P.A. Roff, 1966. Trophic relationships in a small woodland stream. - Verh. Int. Ver. Limnol. 16: 627638.

Carlos L. de la Rosa, Director

La Selva Biological Station

Organization for Tropical Studies

PO BOX 676-2050

San Pedro, Costa Rica.

E-mail: carlos.delarosa@ots.ac.cr 